\title{
Pasado revisitado
}

\section{ALICIA CAMPOS GAJARDO}

Editora Revista de Arquitectura Facultad de Arquitectura y Urbanismo Universidad de Chile

\begin{abstract}
¡ Cómo habitamos hoy?; ¿̇qué singularidades reconocemos en el acontecer de la sociedad actual y la ciudad globalizada?; ¿̇qué transformaciones, emergencias o reinterpretaciones de los programas arquitectónicos convencionales forman parte del desarrollo disciplinar actual? Son algunas de las interrogantes generales que perfilan el ámbito de discusión y análisis de las próximas tres ediciones de Revista de Arquitectura.
\end{abstract}

En términos específicos, siguiendo la línea argumental desarrollada por el filósofo francés Gilles Lipovetsky en el texto Los tiempos hipermodernos (2004), proponemos como hilo conductor de esta aproximación, la noción de tiempo; sus implicancias en la arquitectura y la configuración de la ciudad. De acuerdo a Lipovetsky, la expansión de los mercados financieros, la innovación tecnológica y la valoración de la individualidad por sobre lo colectivo, han configurado una continuidad en exceso, dirigida por una extraordinaria velocidad de cambio que nos invita a comprender las adaptaciones a esta realidad, repensando la habitual relación entre pasado, presente y futuro, y por cierto su inserción en el contexto espacial provisto por la arquitectura.

Si bien ha transcurrido más de una década desde que el texto de Lipovetsky fue publicado, consideramos que este refleja con autenticidad la vida en la sociedad globalizada contemporánea. Pese a que las condiciones de producción y actitud hacia el consumo hoy han cambiado parcialmente, vislumbrándose algunas alternativas adaptativas divergentes o de resistencia; se podría decir que son, en gran medida, coincidentes con las realidades de las ciudades latinoamericanas y su actualidad.

En este sentido, el ámbito de reflexión que plantea el n 33 de Revista de Arquitectura, titulado "Pasado Revisitado", aborda la contingencia de una actitud tensionada por un presentismo que caracteriza a la sociedad contemporánea, modificando nuestra relación con el pasado; observando que los intentos de recuperación y conservación se enfrentan hoy a una cultura de la inmediatez, que tiende a cosificar y caricaturizar acontecimientos y obras del pasado. En el ámbito de la arquitectura, la tensión entre recuperación y renovación, mantención y transformación forman parte del debate actual de la disciplina.

El artículo que inicia este espacio reflexivo, se titula Desenterrando lo olvidado. Cavas Viña Concha y Toro en San Miguel, su autor Felipe Gallardo expone el proceso de puesta en valor de una tipología arquitectónica de reciente estudio, las cavas enterradas en Chile; este proceso desde su documentación y levantamiento hasta el desarrollo de proyecto arquitectónico, tuvo la particularidad de convocar una gestión innovadora, propia del cruce de intereses de los diversos agentes involucrados, lo que sin duda expone las posibilidades de nuevos mecanismos de integración del Patrimonio a la ciudad contemporánea.

En el caso de David Maulén de los Reyes, el artículo Espacio de reactivación de las memorias: edificio UNCTAD III, BiblioGAM evidencia la reinterpretación programática de un emblemático edificio de la ciudad de Santiago, que se inserta en la memoria colectiva apelando a una diversidad de lecturas dadas por la sedimentación de los acontecimientos en el paso del tiempo.

Por su parte, en el artículo Ex Teatro Av. Matta, Santiago de Chile. Puesta en valor de un palimpsesto edificado en tres etapas, sus autoras Karla Pinchón y Carmen Gloria Silva, presentan el caso de un inmueble que ha participado de las dinámicas de la ciudad, primero en una periferia y ahora en un pericentro; sobreviviendo el siglo de existencia, mediante la adaptación silenciosa a nuevos usos 
que conservan cierta continuidad permitiendo reconocer aún sus condición de originalidad y los respectivos cambios materiales y constructivos.

En el ámbito urbano, el arquitecto y académico de la Universidad Arturo Prat, Víctor Valenzuela Gollmus presenta en el artículo Planificación y desarrollo urbano de lquique entre 1930 a 1970, una revisión de los antecedentes documentales para la comprensión de la condición moderna de la planificación de la ciudad de lquique y la complejidad de los factores incidentes en ella, en vista a comprender las problemáticas de su contemporaneidad.

En Paisaje Ciego, vestigios del agua en la ciudad de Santiago de Chile, la arquitecta Camila Kuncar expone los resultados de una experiencia colaborativa, basada en una relectura de antiguas cartografías, en torno a los cursos de agua del Casco Histórico de la ciudad de Santiago de Chile; cuyo reconocimiento in situ evidenció la existencia de una red de acuíferos que abastecieron las edificaciones de la ciudad que actualmente se encuentran en abandono; un hallazgo indocumentado previamente, que nos retrotrae a la relación de la ciudad con el recurso hídrico y el habitar, planteando nuevas preguntas acerca del manejo de este recurso.

Genealogía del Patrimonio Arquitectónico: de documento histórico a recurso reutilizable, es un artículo que presenta una parte de la tesis doctoral de la arquitecta Alberta Lorenza Aspres, teniendo como tema central la problemática de la reutilización, el uso y la pérdida de sentido integral de las edificaciones sometidas a estos procesos. En una revisión histórica pero también crítica, de las tendencias generales que han conducido una teoría del restauro, la autora acota y expone las directrices de un retorno a la continuidad del sentido de las edificaciones para un restauro integral.

Por último, el artículo (A) La conquista de la Atemporalidad de Tuska Arroyo, presenta asimismo un fragmento de la investigación de tesis doctoral (en curso) de la autora, mediante un caso particular, el Great Coxwell Barn, ubicado en Oxfordshire (Inglaterra), único edificio superviviente de las instalaciones agrícolas que se erigieron a las afueras de Great Coxwell, cuyos orígenes se remontan al siglo XIII. A través de una descripción de la condición tectónica del edificio y sus materiales, la autora nos devela la potencial inscripción de la arquitectura en una temporalidad que trasciende la construcción histórica.

La sección Reflexión Estudiantil está representada en esta ocasión por Katherine Moya Farías quien presenta los resultados de su investigación La llusión Caleidoscópica. Dominación cultural en el patrimonio arquitectónico de Santiago, correspondiente a su Tesis para optar al título de Arquitecto, mediante un análisis crítico de representatividad del patrimonio en Chile. El segundo artículo sintetiza el Proyecto de Titulación de Yanko Díaz Toledo, Centro de visitantes para la interpretación y exploración del Paisaje Cultural Pewenche, que tuvo como objetivo contribuir a la puesta en valor de las raíces del pueblo pehuenche, comprendiendo la inexorable vinculación con el entorno natural, y su permanente vulnerabilidad devenida de los requerimientos de la globalización.

Por último, en la sección Reseña presentamos el libro Movilidad urbana y ciudad sustentable. Las experiencias de los casos de Curitiba y de Nantes, en la perspectiva de la sustentabilidad, de la Dra. Natalia Escudero Peña, presentado por la académica Dra. María Isabel Pavés Reyes, documento que retoma las discusiones en torno a las ciudades sustentables; elaboradas en ocasión de la tesis doctoral de su autora, complementando y actualizándolas con nuevos aportes de investigación realizadas recientemente. 